\title{
Linking Remote Sensing, Census and Interview Data to Pesearch $\&$ R Understand Forest Transitions in the Southern Cone of the State of Yucatán, México
}

\author{
Allison Hopkins, Cerian Gibbes, Armando \\ Inurreta Díaz, and Rafael Rojas
}

\section{Research}

\begin{abstract}
Land use land cover change studies have traditionally focused on deforestation processes and their associated drivers, while ignoring or assuming that reforestation processes were the reverse. However, recognition that regrowth processes are equally as complex and important as deforestation processes and play an important role in the large scale functions of tropical forests has led to a growing research interest in forest transitions. In this paper we make a contribution to the understanding of the complex dynamics involved in reforestation, by addressing the question: What are the potential drivers of forest transition in the municipalities of Tzucacab, Peto, and Oxkutzcab in the state of Yucatán, México? Analysis of satellite imagery from the region was used to highlight changes in vegetation between the image dates of 1988, 1994, and 2003. Government census data from 1980, 1990, and 2000 were used to assess the population dynamics and economic trends. In 2005 municipal officials and local market venders were interviewed regarding local land uses. The integration of the results from these analyses suggest that the trend in deforestation between 1988 and 1994 followed by forest regrowth between 1994 and 2003 in all three municipalities can be associated with national government policies, economic development and activities, changes in the spatial hierarchy of the market system, and out-migration.
\end{abstract}

\section{Introduction}

The maintenance of tropical forests is important for regulating global and regional climates (Bonan 2008, Houghton et al. 2000, IGBP 1999, Trivedi et al. 2009) and maintaining ecosystem services and other large scale functions (Daily et al. 2000, Kremen et al. 2000, Naidoo et al. 2008, Schroth \& McNeely 2011). Most work on the relationship between land cover and drivers of its change have focused on deforestation, while reforestation and its drivers are either ignored or assumed to be the reverse process (e.g., Defries et al. 2005, Kinnaird et al. 2003). However, a recognition that regrowth processes are equally as complex and important as deforestation processes and play an important role in the large scale functions of tropical forests has led to a growing research interest in forest transitions (Rudel et al. 2002, Rudel et al. 2005, Southworth \& Nagendra 2010). In this paper we make a contribution to the understanding of the complex dynamics involved in reforestation, by addressing the following question: What are the potential drivers for forest transition in the municipalities of Tzucacab, Peto, and Oxkutzcab in the state of Yucatán, México?

\section{Global drivers of land use/land cover change}

Over the last decade land use/land cover change studies have integrated remote sensing and social science research to foster the identification of socioeconomic drivers for land cover change (de Sherbinin et al. 2002, Geist

\section{Correspondence}

Allison Hopkins, Department of Family and Community Medicine, University of Arizona, Tucson, Arizona, U.S.A.

Cerian Gibbes, Cerian Gibbes, Department of Geography \& Environmental Studies, University of Colorado at Colorado Springs, Colorado Springs, Colorado, U.S.A.

Armando Inurreta Díaz, Universidad Autónoma de Yucatán, Merida, MEXICO.

Rafael Rojas, School of Natural Resources and Environment, University of Florida, Gainesville, Florida, U.S.A.

Ethnobotany Research \& Applications 10:001-013 (2012)

Published: January 03, 2012 
\& Lambin 2002, Geoghegan et al. 2001, Mertens et al. 2000, Nagendra et al. 2003, Turner II et al. 2001). From this integrated research several factors have been identified as driving deforestation in tropical areas around the world including, increasing population density and urban expansion through in-migration; commercialization of timber and agricultural production and the growth of associated markets; policies that foster colonization of forested lands; increasing accessibility to markets through improved transportation; subsidies for unsustainable landbased activities; privatization of land or insecure land tenure; agricultural expansion and intensification; and a decreasing ascription of cultural value to forests.

During the same time period land change scientists also began uncovering evidence of forest maintenance and regrowth in deforested tropical areas (Poyatos et al. 2004, Southworth \& Tucker 2001, Unruh et al. 2005). On a global scale the socioeconomic drivers for forest recovery are diverse and include increasing demand for non-farm labor and associated out-migration; changes in market preferences towards products cultivated under intensive land use; increases in prices for non-timber forest products; changes in public policies such as logging bans and the establishment of protected areas; and increasing respect for sacred areas. The evidence of reforestation coupled with that of forest loss suggests that there are bidirectional changes in forest cover occurring throughout the tropics. The relationship between these bidirectional changes and their associated drivers can best be understood at a local or regional level as the impacts of the drivers on the landscape varies at these finer scales.

\section{Land use/land cover change and associated drivers in the Yucatán Peninsula}

There are several research groups working to understand the dynamics between changes in land cover and land use and drivers of change on the Yucatán Peninsula. The most extensive area of study in the region is the Calakmul Biosphere Reserve and surrounding areas located mostly in Campeche, the southwestern state in the Peninsula. Rueda (2010) determined in an analysis of land cover change that during the period from 1984-1993 the southern tip of the Yucatán Peninsula experienced major deforestation that can be linked to experimental agricultural development in the region and associated increases in the amount of communally held (ejido) lands and households. From 1993-2000 deforestation declined, although this trend varies sub-regionally. For example, in La Montaña a community in the buffer zone outside the biosphere an analysis of satellite imagery revealed an increase in annual deforestation rates from $0.3 \%$ between 1988 and 2000 to $0.7 \%$ between 2000 and 2005 (PorterBolland et al. 2007).

The implementation of neoliberal policies and structural adjustment programs by the Mexican government during the 1990s are important drivers of changes in the Calakmul region. For example based on survey data from 19861997, Programa de Apoyos Directos al Campo (PROCAMPO), an agricultural program implemented in 1994 with the goal of integrating agricultural markets and intensifying production, revealed only modest increases in market production, but an increase in deforestation occurred through the conversion of land to commercial chili production and pastures (Klepeis \& Vance 2003). A study based on household surveys carried out in 1997 and 2003 found that similar land use choices were being made by some, although others were choosing to withdraw from agriculture all together and those who converted their land to pasture or commercial agriculture were using less land than previously devoted to extensive agricultural practices, resulting in a decrease in deforestation (Busch \& Geoghegan 2010, Radel et al. 2010, Schmook \& Radel 2008). The increase in global environmentalism over the last 25 years has also led to the development of community-based conservation programs in the region, such as the Parks in Peril program and Empleo Temporal, which along with the enforcement of rules associated with the reserve seem to be contributing to a decline in deforestation (Rueda 2010).

Demographic and cultural drivers are also playing a role in land use choices in the southern portion of the peninsula. An important contributor to the decline in deforestation is a reduction in family labor due to out-migration and the resulting decrease of land in production (Busch \& Geoghegan 2010, Radel, et al. 2010, Schmook \& Radel 2008). The relationship that people have with the land and their land use choices also depends on their length of residence in the area, with long-time residents typically practicing diversified subsistence strategies that have less of an adverse environmental impact than the commercial agriculture typically practiced by immigrants from central and northern México who moved to the region during the agrarian reform of 1994 (Chowdhury 2010, Gurri 2010).

Land cover change in Quintana Roo, the southeastern most state located in the Yucatán Peninsula, varied. Garcia et al. (2007) predicted a slight increase in area covered by medium stages of secondary forest in northeastern Yucatán peninsula by 2011 using vegetation maps from 1997 to 2003. An analysis of Landsat images from the Maya region in central Quintana Roo revealed little change in forest cover with net deforestation of $0.01 \%$ during the period from 1984 to 2000 (Bray et al. 2004). A more localized analysis of land cover change in Senor, communally held (ejido) lands in central Quintana Roo, between 1976 and 1997 showed a shift in landscape from one dominated by heterogeneous tracts of land in different successional stages, including mature forest, to one consisting almost exclusively of young fallows (Dalle et al. 2011). 


\section{Hopkins et al. - Linking remote sensing, census and interview data to understand forest transitions in the state of Yucatan, Mexico}

There are various regional and local factors associated with the land cover change in Quintana Roo. Predicted increases in forest cover were linked to the incorporation of ecotourism activities by the Yucatec Maya in the northeastern Yucatán Peninsula as the result of increased global environmentalism (Garcia-Frapolli et al. 2007). Additionally, neoliberal agricultural reforms have negatively affected traditional agriculture, while neoliberal tourism development has privileged working in the tourism sector as a more viable livelihood strategy (Carte et al. 2010). Policies leading to the establishment of large common property forests for non-timber forest product extraction and institutions to manage these forests sustainably are critical in maintaining existing forest cover (Bray et al. 2004). Increases in deforestation in the region may be due to agricultural expansion and intensification as a result of the implementation of a community forestry program in 1984 (Plan Piloto Forestal), in-migration, increase in wage labor and off-farm activities, changes in agricultural policies, and the increase of non-ejiditarios (Dalle et al. 2011).

Only a few studies of land use/land cover change have occurred in the state of Yucatán, the third and northern most state comprising the peninsula by the same name. Sohn et al. (1999) found that agricultural land use intensified from 1985 to 1995 in the central part of the state resulting in a landscape that consists mostly of agricultural fields and land in early stages of secondary succession with advanced secondary succession and young forests limited to communal forest reserves and private ranches. Analysis of land cover change from 1988 to 2001 at a fine scale within the municipality of Peto in the southern cone of the state of Yucatán reveals that agricultural expansion occurred from 1988 to 2001 followed by a shift to forest regeneration from 2001 to 2005 (Hartter et al. 2008). Information from landholders suggested that agricultural intensification practices may have played a role in this shift. Wyman et al. (2007) also identified government-sponsored agriculture assistance, along with better soil quality, as important factors in larger forest clearings in Tzucacab compared to its neighboring municipality of Peto in the southern cone of the state of Yucatán.

\section{Site Selection}

Tzucacab, Oxkutzcab, and Peto, three municipalities in the southern cone of Yucatán State, México, were selected to carry out this study not only because several drivers associated with forest transition are impacting land use in this region, but also because carrying out research in this region allows us to better understand three gaps in land use and land cover change and conservation research. The first gap is the lack of attention given to the drivers of reforestation. Most land use and land cover change research has been directed towards understanding deforestation and associated drivers while ignoring regrowth and its drivers or assuming the process to be the reverse of deforestation (Aide \& Grau 2004). In this study we identify increases in forest cover and provide plausible explanations for this change.

A preference by scientists for carrying out ecologically related research in unpopulated areas has resulted in a void in understanding of how changes in forest cover occur in anthropogenic landscapes (Hecht 2010). The state of Yucatán is a particularly good place to start to fill this second gap because, in addition to the practice of slash and burn agriculture for the last 3,000 years by the Maya (McKillop 2004), it is also the most populous of the three states in the peninsula and it has the least land area designated for protection from human impact (CONANP 2011, INEGI 2011, SEDUMA 2011).

Lastly, conservation and research efforts have generally focused on humid tropical forests, even though habitat conversion in tropical dry forests is much greater (Hoekstra et al. 2005). Our case study in the state of Yucatán consists primarily of deciduous tropical dry forest in various stages of succession, whereas Quintana Roo and Campeche, the locations of the majority of land use/land cover change studies in the region, are generally wetter and consist mostly of semi-perennial tropical forest (Salvador Flores \& Espejel Carvajal 1994). A complete description of the municipalities under study, including changes in livelihood strategies and land cover is discussed in the results section.

\section{Methods}

The overarching goal for this study was to link changes in land cover based on satellite imagery to interview and census data to determine potential drivers of land cover change in the municipalities of Tzucacab, Peto, and Oxkutzcab, in the state of Yucatán, México. Our specific objectives were:

1. Detect change in vegetation cover in the municipalities of Tzucacab, Peto, and Oxkutzcab on satellite imagery over the period of 1988-2003.

2. Compare change patterns across the three municipalities.

3. Identify potential drivers of forest change from census and interview data.

4. Relate potential drivers to patterns of change in forest cover.

The utilization of a combination of methods is increasingly common in studies of the drivers of landscape change because of its effectiveness at illuminating the complex reasons why changes in forest cover occur (Walsh et al. 2008). We have used this approach here with the intent of uncovering preliminary, but plausible, explanations for landscape change in this region that can be further explored in more extensive studies. 
Ethnobotany Research \& Applications

A multi-temporal multi-spectral dataset consisting of Landsat imagery from 1988, 1994, and 2003 was used to measure change in forest cover. These particular time points were selected because they were the highest quality images available during the time when neoliberal policies, a potential driver of change, were first implemented and subsequently incorporated into the daily lives of the Yucatecans. Image preprocessing procedures were conducted on all images to correct for sensor drift and atmospheric differences, thereby decreasing the chance of identifying change at the sensor level rather than on the earth's surface. An unsupervised classification process, where the images are processed based solely on image statistics, was used to identify forest and agricultural areas within the landscape. Differentiation between agricultural types was not done, as field observations indicated that with regard to the continuous analysis of land cover (discussed below) aggregation of agricultural types would be appropriate. These two land cover classes were focused on as opposed to characterizing change across all possible land covers within the study area, since much of the deforestation in the Yucatán peninsula follows primarily from agricultural expansion (Geoghegan, et al. 2001). The unsupervised classification was validated with field observations of land cover collected using the CIPEC protocol (Green et al. 2005). The protocol requires users to record GPS location of observations, and observations consist of: topographical information, land cover type, vegetation structure, species presence, and land history.

Changes in land cover within the areas identified as forest and agriculture by the unsupervised classification were assessed using a continuous remote sensing methodology - Normalized Difference Vegetation Index (NDVI). NDVI enables a continuous measure of landscape change reducing the simplification of land cover dynamics and ensuring that changes within land cover classes (i.e., within forest or within agriculture) can be detected. NDVI is a comparative ratio index which relies upon measures of near infrared and red energy (NIR - red/ NIR + red). A change threshold of $20 \%$ was identified as a suitable filter to limit the inclusion of small fluctuations in NDVI in the land cover change analysis, and ensure that only major changes and broad landscape trends were highlighted. We assessed both decreases and increases in NDVI, allowing both deforestation and re-growth to be recognized. The change detection analysis was repeated for each municipality.

Census data were included in this study to provide a general overview of the socioeconomic conditions of the study area, detect changes in patterns over time, and determine plausible links between these changes and changes identified in the land cover analysis. During March 2005 we visited the Instituto Nacional de Estadística y Geografía (INEGI) office in Mérida, Yucatán and acquired all the available information from the 1980, 1990, and 2000 Mexican national censuses for the three municipalities of interest. We selected those three censuses because they covered approximately the same time period as the satellite imagery. We choose to focus our analysis on population dynamics and economic activities because changes in these two areas are frequently associated with changes in livelihoods and land use choices, which are in turn manifested in land cover changes and are detectable using satellite imagery (Wood \& Skole 1998). In each of these areas we selected key indicators and calculated growth ratios and distribution indexes to measure change temporarily and make comparisons across municipalities. In regards to population dynamics we focused our analysis specifically on changes in population growth rates, mobility, and the concentration of people in urban centers across time in each municipality. We created age structure pyramids to identify out-migration patterns. Our analysis of economic activities measured change in the prevalence of the working population among different economic sectors.

During one week in March 2005 we carried out key informant interviews in the cities of Oxkutzcab, Peto and Tzucacab, the capitals of the municipalities by the same name. The overarching purpose of the interviews was to garner an initial understanding of the production and consumption patterns of agricultural goods. Using semistructured interviews which included a mix of closed and open ended questions, we interviewed two types of key informants, municipality officials in charge of monitoring agricultural practices/economic activities and venders of agricultural products in the municipal markets. The questions for the informants were focused on what agricultural products from their municipality are produced for sale as opposed to household consumption and the origin of the agricultural products they were selling. Opportunistic sampling was used to identify informants. Based on the number of informants available and the limited time we were able to dedicate to collecting data, we interviewed a government official in each municipality and two market sellers in Tzucacab and three in Peto and Oxkutzcab each. The key informant interviews were designed to further our understanding of local integration into the global marketplace with a particular emphasis on agricultural production because of its implications for impacting land use decisions, which in turn have the potential to impact land cover.

\section{Results}

\section{Remote sensing analysis}

The land cover change analysis allowed for detection of land cover trends in the southern cone of Yucatán State and in the municipalities of Tzucacab, Peto, and Oxkutzcab between the period of 1988 and 2003 (Figure 1). The use of a change threshold of $20 \%$ enables the identification of more obvious changes and general trends across the landscape which is the main focus of this work, however, it limits the assessment of the impact of land uses (e.g., selective logging) which result in more subtle 

understand forest transitions in the state of Yucatan, Mexico

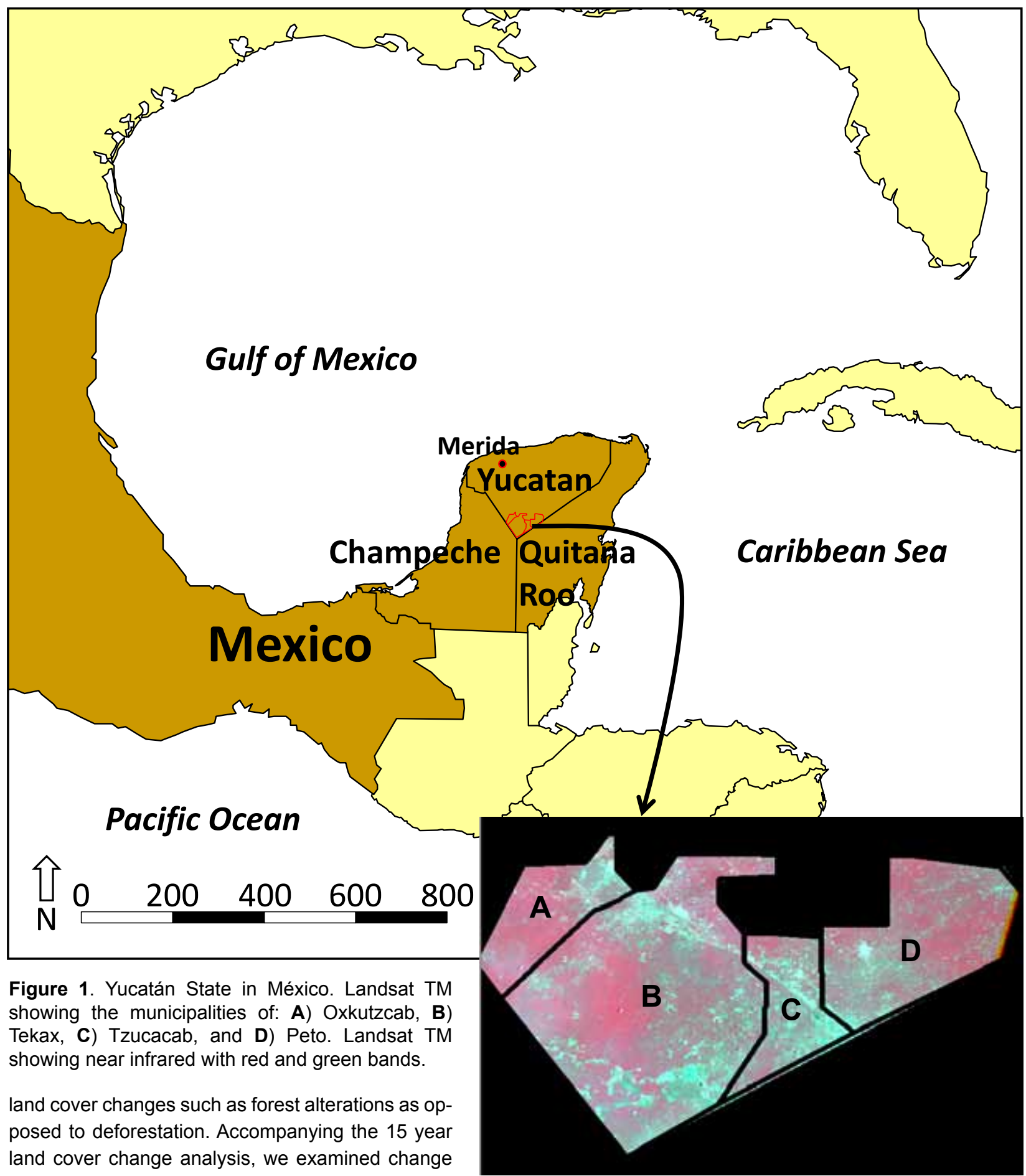
at each time interval (1988 through 1994 and 1994 through 2003), and changes in land cover were compared within each municipality. Lastly, the land cover change findings are compared with the census and key information interviews to determine if there are any associations.

One limitation associated with the use of Landsat data is the temporal availability of high quality imagery during the time period of interest. Due to the static nature of the

dataset, the analysis highlights changes that occurred at the temporal resolution of the dataset and is unable to account for changes at shorter time intervals. The lack of knowledge of the status of the landscape during the intervening time periods is a limitation associated with most remote sensing analyses. Nonetheless, the analysis is able to capture consist trends in land cover across the three municipalities. 
Between 1988 and 2003, an increase in NDVI was measured across $14 \%$ of the entire study area suggesting that vegetation regrowth occurred there (Table 1). This is contrasted with only $3 \%$ of the area losing forest cover as measured by decreases in NDVI values. Slightly more than a third $(35 \%)$ of the study area experienced change below the $20 \%$ threshold, possibly indicating small alterations to forest cover occurred in that portion of the study region. Almost half $(48 \%)$ of the land area experienced no change.

Table 1. Measure of percent of area where the Normalized Difference Vegetation Index changed across and within the municipalities of Tzucacab, Peto, and Oxkutzcab, Yucatán, México between image dates (1988-2003, 19881994, 1994-2003).

\begin{tabular}{|c|c|c|c|}
\hline \multirow[b]{2}{*}{ Municipality } & \multicolumn{3}{|c|}{$\%$ Area Change } \\
\hline & $1988-2003$ & 1988-1994 & 1994-2003 \\
\hline \multicolumn{4}{|c|}{ Entire Study Area } \\
\hline Decreased & 3 & & \\
\hline Increased & 14 & & \\
\hline Unchanged & 48 & & \\
\hline \multicolumn{4}{|l|}{ Tzucacab } \\
\hline Decreased & 5 & 26 & 0 \\
\hline Increased & 4 & $<1$ & 46 \\
\hline Unchanged & 54 & 54 & 53 \\
\hline \multicolumn{4}{|l|}{ Peto } \\
\hline Decreased & 3 & 50 & $<1$ \\
\hline Increased & 7 & $<1$ & 50 \\
\hline Unchanged & 38 & 39 & 38 \\
\hline \multicolumn{4}{|l|}{ Oxkutzcab } \\
\hline Decreased & $<1$ & 0 & $<1$ \\
\hline Increased & 33 & $<1$ & 41 \\
\hline Unchanged & 58 & $<1$ & 59 \\
\hline
\end{tabular}

In Tzucacab between 1988 and 1994, NDVI values increased in $26 \%$ of the municipality, while less than $1 \%$ decreased and $54 \%$ of the area was unchanged. From 1994 to 2003 there was a large increase in vegetation (46\%) and no detectable decrease in vegetation. Similar to the previous time period a little over half $(53 \%)$ of the land cover was unchanged. When looking at the change that has occurred over the entire time period between 1988 and 2003 the amount of land that has decreased and increased in NDVI value is similar with $5 \%$ and $4 \%$ change, respectively. The remainder of the area in Tzucacab was either unchanged $(54 \%)$ or experienced change below the chosen threshold (37\%).

The greatest decrease in vegetation occurred in the municipality of Peto between 1988 and 1994, with $50 \%$ of the municipality having a decrease in NDVI value. During this same time period less than $1 \%$ had an increase in NDVI value and $39 \%$ of the land cover remained unchanged. The largest amount of area with an increase in NDVI value occurred between 1994 and 2003, when $50 \%$ of the municipality had an increase in vegetation cover. Analysis between images taken in 1988 and 2003 revealed that 3\% of the area within the Peto had a decrease in NDVI value while roughly $7 \%$ of the area experienced an increase in NDVI value.

Oxkutzcab experienced very little increase $(<1 \%)$ or decrease $(0 \%)$ in area of vegetation cover between 1988 and 1994. During this same time period there was also very little area that remained unchanged $(<1 \%)$. From 1994 to 2003 much of the land in Oxkutzcab increased in NDVI value (41\%), while less than $1 \%$ decreased and $59 \%$ remained unchanged. During the entire time period of interest (1988-2003) a decrease in NDVI value in less than $1 \%$ of the total area of Oxkutzcab was exhibited, an increase in NDVI value in $33 \%$ of the area occurred and over half $(58 \%)$ of the land remained unchanged in vegetation cover.

\section{Census data}

The population throughout the entire study area grew from 1980 to 2000 (Figure 2). Tzucacab's population increased from 8,184 people (1980) to 11,108 (1990) to 12,577 (2000). By 2000 the population density in the municipality was 9.75 people per square kilometer. Peto had 15,159 (1980), 19,227 (1990), and 21,284 (2000) people living in the municipality. The number of inhabitants in Peto

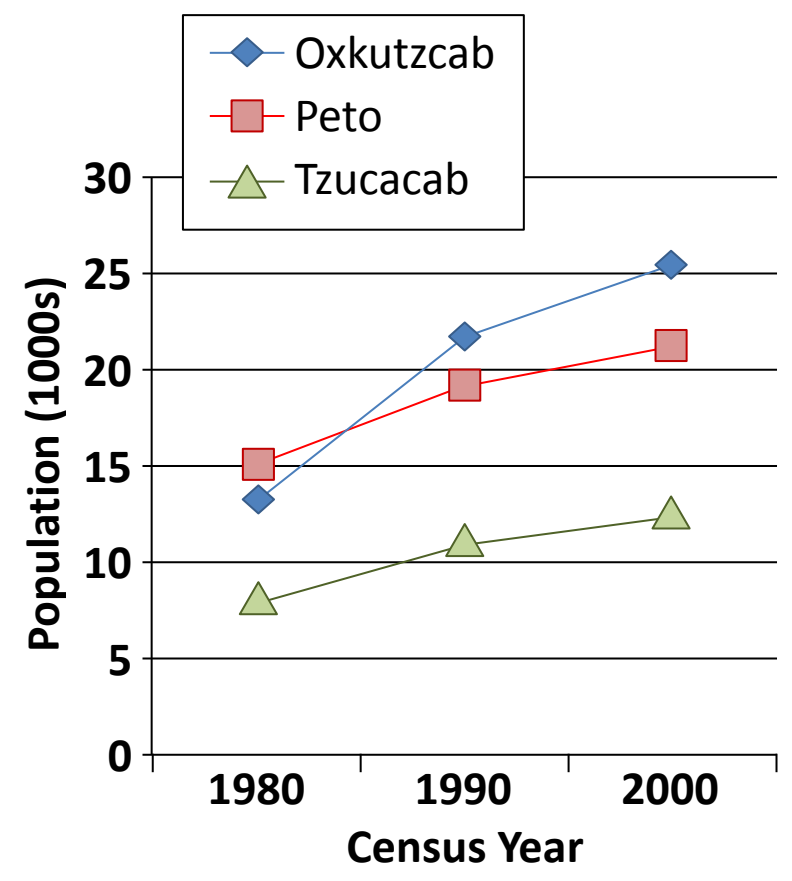

Figure 2. Population growth between 1980-2000 in the municipalities of Tzucacab, Peto, and Oxkutzcab, Yucatán, México. 


\section{Hopkins et al. - Linking remote sensing, census and interview data to understand forest transitions in the state of Yucatan, Mexico}

throughout the study period was greater than Tzucacab although the population density of 6.79 people/ $\mathrm{km}^{2}$ per square kilometer in 2000 was less than in Tzucacab because Peto's territory is larger. Oxkutzcab was the municipality with the greatest number of inhabitants with 13,281 (1980), 21,639 (1990), and 25,483 (2000).It also had the greatest population density with 49.75 people $/ \mathrm{km}^{2}$ (2000).

The most striking feature of population dynamics in the study area was the decline in the growth rates in all of the municipalities during the period between 1990 and 2000 as compared to the prior decade (Table 2). Tzucacab's population growth was $36 \%$ between 1980 and 1990 then dropped to $13 \%$ during the next decade. Peto had less growth than Tzucacab with $27 \%$ from 1980 to 1990 and $11 \%$ from 1990 and 2000. Oxkutzcab had the greatest growth between 1980 and 1990 (63\%) and in the latter decade the population growth reduced to $18 \%$.

Table 2. Intercensal population growth within the municipalities of Tzucacab, Peto, and Oxkutzcab, Yucatán, México based on the 1980, 1990, and 2000 census data

\begin{tabular}{|l|c|c|}
\hline \multirow{2}{*}{ Municipality } & \multicolumn{2}{|c|}{ \% Population Growth } \\
\cline { 2 - 3 } & $\mathbf{1 9 8 0 - 1 9 9 0}$ & $\mathbf{1 9 9 0 - 2 0 0 0}$ \\
\hline Oxkutzcab & 63 & 18 \\
\hline Peto & 27 & 11 \\
\hline Tzucacab & 36 & 13 \\
\hline
\end{tabular}

Another population trend in all three municipalities was a higher concentration of people in the three municipal capitals during the earlier decade $(78 \%)$ as compared to the latter decade (66\%). In addition, the age pyramids indicate that the greatest percentage of people in each municipality were under the age of 20 in 2000, with a sharp decline in the percentage of people between the ages of 20 and 40 and a much more gentle decline from age 40 and up. Although this pattern is present in all the municipalities during the entire study period, it is most clear in Peto in 2000 (Figure 3).
The economic activities in the three municipalities varied to some extent. In 2000 the least populated municipality, Tzucacab, was the most dependent of the three municipalities on agriculture $(51 \%$ of the laborers in the municipality were employed in this sector) with only $31 \%$ of the employment in the service sector (Figure 4). Peto, the municipality that was intermediately populated, relied on agriculture $(43 \%)$ for most of the jobs followed closely by the service sector (35\%). Oxkutzcab had the largest service sector $(44 \%)$ of the municipalities, including mainly commerce and tourism. The agriculture sector provided $40 \%$ of the jobs in the municipality. The importance of manufacturing as a source of work was approximately equal across the three municipalities; $10 \%, 10 \%$ and $8 \%$ in Tzucacab, Peto, and Oxkutzcab, respectively. The remaining jobs were placed in the other category.

\section{Key informant interviews}

Although the three municipalities are near one another, land tenure and agricultural production were quite distinct. In Tzucacab $58 \%$ of the land was privately owned and $42 \%$ was ejido land, which is land owned communally by the members of the ejido. This municipality had the least amount of land in commercial production $(20 \%$ of the total land area) as compared to the other municipalities. The rest of the land was devoted to subsistence farming. Almost as much land was in pasture $(1,000$ hectares) in Tzucacab as was in agricultural production $(1,250$ hectares).

In the 1980s agricultural producers in Tzucacab primarily grew corn, beans, tomatoes, watermelon, jalapeno peppers, and jicama. The ranchers primarily bred cattle and pigs. They also produced poultry and eggs for internal consumption with the excess sold to other municipalities, principally Peto and Tekax (SEGOB 1988). Based on the market vender interviews the major agricultural products in Tzucacab in 2005 had shifted to honey, lemons, and oranges; lemons were sold locally, whereas honey and oranges were exported. Most of the commerce in this town

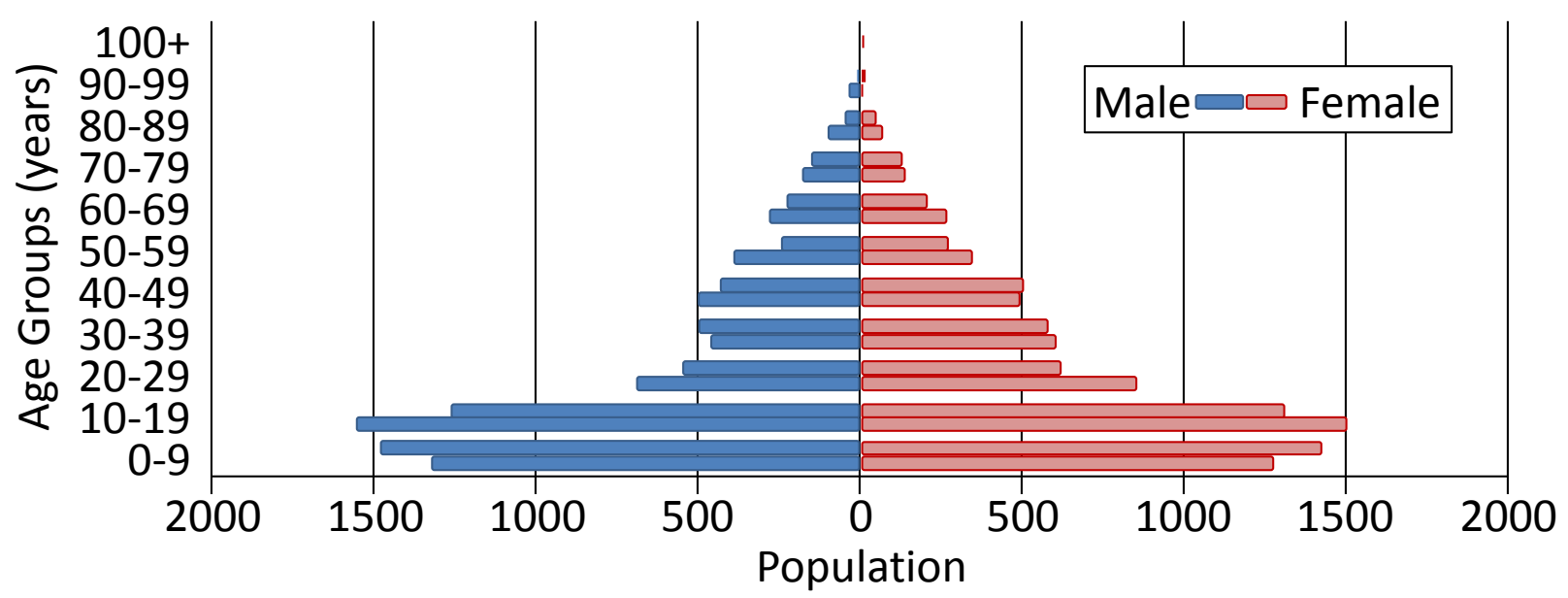

Figure 3. Age pyramid for the municipality of Peto, Yucatán, México based on the 2000 census data. 


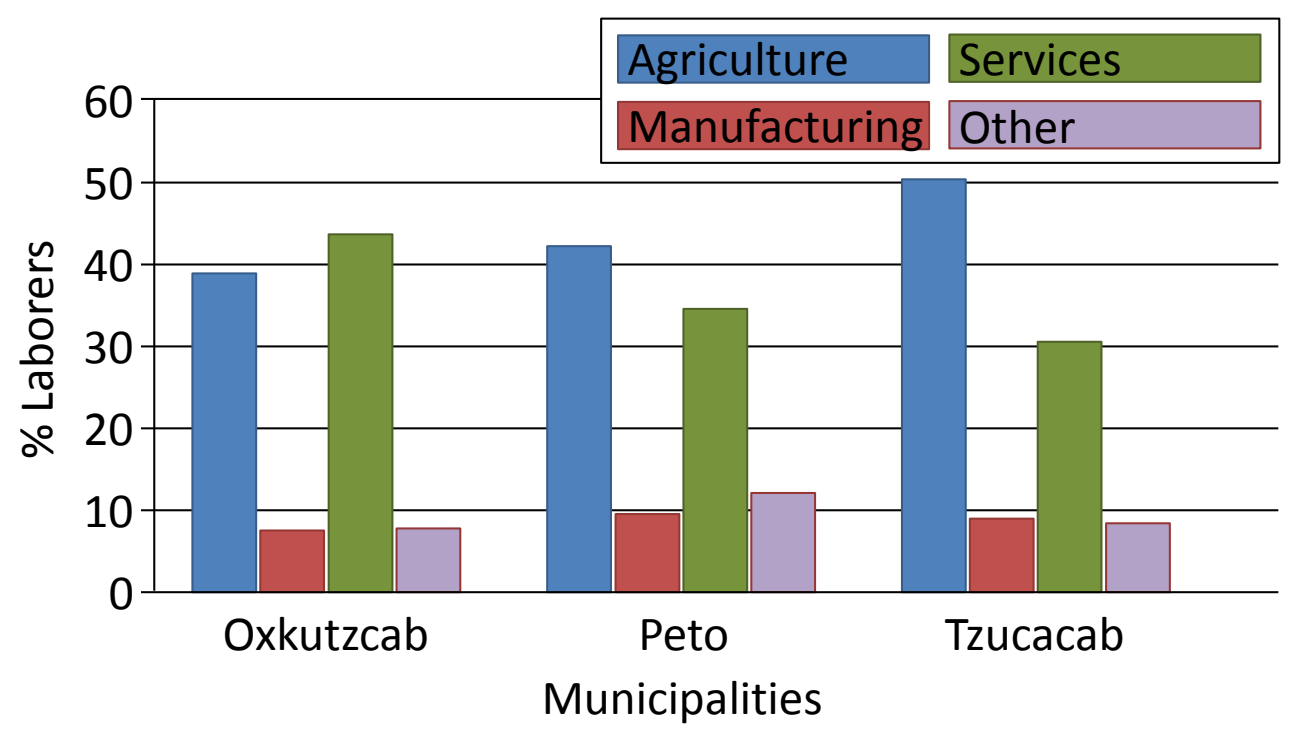

Figure 4. Economic activity for the municipalities of Oxkutzcab, Peto, and Tzucacab, Yucatán, México based on 2000 census data.

was focused on basic necessities. The only tourism in the municipality was the archaeological site Ek Balam, of the same name as the far better known site on the far eastern side of the state of Yucatán.

The vast majority (90\%) of Peto's land was designated ejido land and only $10 \%$ was privately owned $(10 \%)$. A quarter of the land in this municipality was devoted to commercial production and the other three-quarters to subsistence agriculture. In contrast to Tzucacab, much more of the land in Peto was in agricultural production $(60 \%)$ than pasture (8\%).

The major crops grown in the municipality of Peto during the 1980s were corn, beans, and watermelon (SEGOB 1988). Also ranchers produced cattle, pigs, and poultry. During that time livestock producers received subsidies from Banco Rural (an organization that provided loans to agricultural producers), insurance from the Aseguradora Nacional Agrícola Ganadera (ANAGSA) and production advice from the Secretaria de Agricultura y Recursos Hidraulicos (SARH). The removal of these services during the neoliberal period likely led to a reduction in livestock production and explains the low percentage of land dedicated to animals in 2005. Shoe and clothing manufacturing also occurred in the municipality in the 1980s (SEGOB 1988). Key informants reported that from 1995 through 2005 Peto increased its production of habanero peppers for export. Beans, corn, and string beans were also exported from the municipality. Achiote, habanero peppers, cilantro, lettuce, oranges, squash, tomatoes, and radishes were produced in the municipality and sold in the municipal farmer's market. There were a few hotels in the city of Peto but otherwise there was no tourism infrastructure. The commercial sector was dominated by grocery stores with prepackaged foods.
Oxkutzcab, like Peto, also had a large amount of land in ejido (89\%), only a small percentage was privately owned $(2 \%)$ and $9 \%$ of the land was owned by agricultural unions. A large portion of the total land in Oxkutzcab was used for commercial production $(80 \%)$ with the remaining $20 \%$ farmed for home consumption. In Oxkutzcab none of the land was in pasture and the rest of the land in production was in agriculture (60\%). Oxkutzcab has experienced burgeoning labor relationships brought on by globalization through a large increase in Agricultural Unions over the last ten years. In 2005 there were 70 Unions with about 40 people per organization, which was about 2,800 people participating in total. Greater organization of the farmers has resulted in more extensive linkages to national and international markets and impacted what the farmer's choose to produce on their lands.

During the 1980s corn, beans, watermelon, and tomatoes were grown in the municipality of Oxkutzcab (SEGOB 1988). Ranchers produced poultry, bees, bovine cows, pigs, and goats and received the same subsidies, insurance, and production advice as those from Peto. Similar to Peto, the complete lack of land in livestock production in 2005 suggests that the removal of government support led to a shift in agricultural production from livestock to other areas. Commerce has expanded beyond basic necessities in the county seat (SEGOB 1988). Interviews with key informants in 2005 revealed that farmers in Oxkutzcab were becoming large producers of oranges for export. In addition, they exported beans, honey, and the mamey fruit. Avocados, habanero peppers, cucumbers, lemons, mangos, squash, and tomatoes were all locally grown and sold at the municipal farmer's market. Tourism was a bit more prominent in this municipality in comparison to Tzucacab and Peto. There were tourist establishments set up in the city of Oxkutzcab and there were 


\section{Hopkins et al. - Linking remote sensing, census and interview data to understand forest transitions in the state of Yucatan, Mexico}

natural and cultural attractions in the municipality like the caves of Lotún and archaeological sites like Sayil and Labná, Xlapak, Kom, Sabacché and Kiuic along with CoIonial attractions.

The interviews with venders revealed that in Tzucacab only $4 \%$ of the produce sold by the interviewed venders was grown within the municipality (Table 3). Peto had the largest amount of locally grown produce with half of the produce sold by the venders interviewed originating in the municipality. While approximately a quarter $(24 \%)$ of the produce sold in Oxkutzcab was locally grown.

Table 3. Quantity of agricultural products sold in each municipality (Oxkutzcab, Peto, and Tzucacab, Yucatán, México) and the percentage of those agricultural products sold that were produced locally.

\begin{tabular}{|l|c|c|}
\hline & \multicolumn{2}{|c|}{ Local Agricultural Products } \\
\hline Municipality & \# Sold & \% Produced \\
\hline Tzucacab & 25 & 4 \\
\hline Peto & 18 & 50 \\
\hline Oxkutzcab & 29 & 24 \\
\hline
\end{tabular}

The venders described the system of distribution, which allowed them to sell produce from around the world. All of the venders in Tzucacab and Peto explained that they receive their non-locally grown produce from Oxkutzcab which was the produce distribution center for southern Yucatán State. The venders in Oxkutzcab told us that they receive their non-local produce from México City. The distribution center in México City received produce from all over México and others parts of the world. For example, much of the produce that requires cooler temperatures to grow, such as grapes and apples, were from Chile or the United States. The venders explained that the produce was transported from the market centers to the smaller towns across México by an intermediary. The venders bought the produce from the intermediary and then they sold it in the market. One vender from Peto explained that this system of produce distribution began around 1992 as a result of a federal government neoliberal project. Before this project was implemented people were producing and selling locally.

\section{Discussion and Conclusions}

In comparing the results from the remote sensing analysis of the three municipalities some general trends emerge. Overall the pattern of change shows a period of deforestation in Tzucacab and Peto between 1988 and 1994. From 1994 to 2003 a period of reforestation occurs in all three municipalities. Over the entire study period Oxkutzcab net increase in forest cover was much greater than the other two municipalities. This general trend is similar to that found in other areas of Peto and in the Calakmul region of Campeche (Hartter et al. 2008, Rueda 2010).
Although the population grew throughout the entire study area from 1980 through 1990, there was a decline in the population growth rate during the 1990s. Tzucacab and Peto experienced a reduction in growth rates by over half and Oxkutzcab experienced the greatest reduction with its growth rate slowing to one-third of the previous decade. The high growth rates during the 1980s and the subsequent decline in the 1990s can at least be partially explained by high rates of migration from the rural areas to municipal centers during the 1980s and then from municipal seats to national and international urban centers during the 1990s, as indicated by the higher concentration of people in the regional urban centers during the earlier decade as compared to the latter. The age pyramids from 2000 also indicated that there was an out-migration during the 1990s because of the reduced presence of 20 to 40 year olds, which is the age range when people are most physically able to be productive in manual labor positions (Siegel \& Swanson 2004).

According to the key informants in each municipality, many of their youth were leaving for jobs in construction for tourism in Cancun or moving to cities, like Merida, and to the United States to seek out work in the construction or service industries. Migration to San Francisco, California was so common in Oxkutzcab that the town's people paid tribute to the city by painting a mural of the Golden Gate Bridge, a common San Francisco icon, in the town square. The officials explained that migration of the youth resulted in a paucity of people to work the land in all of their municipalities. Oxkutzcab was the only place that was experiencing any in-migration, but none of it was related to agriculture. Out-migration was also linked to a reduction in area under cultivation in the Calakmul region (Busch \& Geoghegan 2010, Radel, et al. 2010, Schmook \& Radel 2008). The 2000 census data showed that the service sector is the most important source of employment in Oxkutzcab whereas agriculture continued to provide the main source of livelihood for people in Peto and especially Tzucacab.

The interviews with produce venders in the southern cone of the state of Yucatán exposed the large degree with which these communities in the southern Yucatán are economically connected both regionally and globally. Venders in Tzucacab, the municipality with the lowest percentage of land in commercial agricultural production and the greatest percentage of land dedicated to subsistence farming and raising cattle, were selling the least amount of locally grown produce. A greater percentage of land in Peto was devoted to both commercial and subsistence agriculture than Tzucacab and produce venders were selling the greatest amount of produce grown in the same municipality as compared to the other two municipalities. Oxkutzcab was dominated by commercial agriculture production with no evidence of cattle ranching and an intermediary amount of locally grown produce was sold there. A complex pattern of livelihood strategies also occurs in 
the southern region of the Yucatán Peninsula, including subsistence maize, commercial chili cultivation, wage labor, pasture production, and conservation land uses such as harvest of non-timber forest products (Chowdhury 2010, Dalle et al. 2011). The hierarchical system of distribution that was implemented in the southern cone of the state of Yucatán as a result of a neoliberal federal policy also reveals the connections between local markets and global agricultural production, as does the increase in commercial chili pepper production in Campeche (Keys 2004, Klepeis \& Vance 2003).

The findings from the census and interview data point to neoliberal government policies as an important driver of land cover change in the southern cone of the state of Yucatán. Neoliberal policies likely led to a reduction in the amount of land under production by ending programs that favored land extensive cattle ranching in Peto and Oxkutzcab and creating a market distribution system that restructured the flow of goods and favored intensive commercial production of agricultural products. In this new market system Oxkutzcab became the regional market center and governed the commercial flow of goods in the southern State of Yucatán. This position has allowed Oxkutzcab to develop an economy based heavily on services and intensive commercial agriculture production. In contrast, Tzucacab and Peto remain more reliant on land extensive subsistence agriculture. The impact of these choices on land cover is apparent from the differences in land cover change between municipalities. From 1988 through 2003 Oxkutzcab experienced a much greater area of increase in vegetation cover across the municipality as compared with Tzucacab and Peto. This can be partially explained by the greater degree of out-migration that was experienced in Oxkutzcab, but it is also explained by the rapid modernization Oxkutzcab has undergone as a result of neoliberal policies.

Neoliberal policies have also reduced government support for traditional agricultural practices and decreasing the price of surplus corn, which have led to increased household economic pressures (Robson 2010). These changes have occurred in conjunction with increasing offfarm economic opportunities in urban centers throughout the peninsula and abroad. The result is a push-pull effect that encourages rural people to abandon their traditional agricultural practices and their communities to seek employment in urban centers. This process has occurred all across the Yucatán Peninsula (Carte et al. 2010, Chowdhury 2010) and is likely another important driver of forest transition in this region. The informants reported that outmigration has resulted in lack of laborers to work in the local agricultural plots, which has led to land abandonment. Land abandonment over time results in the regrowth of forest (Poyatos et al. 2004), as was seen in our land cover change analysis which indicated increases in forest cover as measured by NDVI during the latter half of the study time period in the three municipalities.
Increases in forest cover are generally considered a desirable outcome in conservation because of the association with increases in a range of ecosystem services however, when forest cover increases occur as a result of out-migration or the unintended consequences of government policies as opposed to sustainable management plans, the societal risks potentially outweigh the benefits of increased forest cover. For example, greater dependence on external food sources may lead to food insecurity if these sources become unreliable. More dependence on wage labor, if these sources are unreliable, may also lead to greater overall household insecurity. Out-migration has the negative consequence of splitting up the family and reducing the social support available for its members. Community institutions struggle to remain operational (Robson \& Berkes 2011a). Greater dependence on low labor, but high chemical input agricultural practices, has negative health consequences through direct exposure to the chemicals and the potential contamination of the water supply. Decreases in biodiversity can also occur through afforestation because they lead to a reduction in traditional agricultural practices that resulted in a "high biodiversity forest-agriculture mosaic" (Robson \& Berkes 2011b). At a broader scale out migration shrinks the workage population of the sending community and potentially leads to increases in spatial disparities in development (de Haas 2010).

The identification of regrowth between 1994 and 2003 is an interesting finding, however, the analysis presented here simply provides an initial assessment of the linkages between vegetation change patterns and globalization related drivers and as such further research is required to expand upon the relationships proposed here. The change detected in the study had to be greater than the pre-defined threshold, allowing small yet possibly important changes to go undetected. Finally, these findings can be improved by better matching the satellite imagery with the census data and interviews and by increasing the breadth and depth of the qualitative interviews. Despite these shortcomings, this study provides a useful example of the value in triangulating multiple types of data collection and data analysis to create a more holistic view of land cover change and as an aid in identifying both proximate and distant driving factors. Additionally, the use of an interdisciplinary approach to assess land cover change validated by fieldwork enhances and cross validates the individual analyses.

This study provides an initial examination of the complex dynamics among government policies, land cover and rural communities. Future multi-disciplinary collaborative research in the form of longitudinal studies is needed to assess in greater detail the local and regional impact of government policies on forest composition, land use, and the well-being of rural dwellers over time. Specific extensions to this research may include assessing the following questions: How do varying agricultural practices (i.e., 


\section{Hopkins et al. - Linking remote sensing, census and interview data to understand forest transitions in the state of Yucatan, Mexico}

ranching vs. farming, subsistence vs. commercial production) influence changes in landscape patterns? How are the risks associated with changes brought on by neoliberal policies impacting rural dwellers and their livelihood decisions? How are changes in land use impacting biodiversity? Are shifts from more traditional agricultural practices to commercialized practices leading to a loss in valuable germplasm? Research addressing such questions and explicitly incorporating methods and analyses that aims to examine the linkages between policy, landscape dynamics, and rural living is imperative to the design of policies at all scales which explicitly foster improvements in the well-being of rural dwellers and the environment within which they live.

\section{Acknowledgements}

The authors are grateful for the support provided by the National Science Foundation Working Forest in the Tropics Integrative Graduate Education and Research Traineeship grant (0221599) used to carry out this research, and the National Center for Complementary and Alternative Medicine at the National Institutes of Health grant (T32AT001287) used to write the article. We are appreciative of the editorial comments provided by Jane Southworth and the anonymous reviewers. A special thanks to the municipal authorities and the market salespeople with which we spoke.

\section{Literature Cited}

Aide, T.M. \& H.R. Grau. 2004. Ecology - Globalization, migration, and Latin American ecosystems. Science 305(5692):1915-1916.

Bonan, G. 2008. Forests and climate change: forcings, feedbacks, and the climate benefits of the forests. Science 320(5882):1444-1449.

Bray, D.B., E.A. Ellis, N. Armijo-Canto \& C.T. Beck. 2004. The institutional drivers of sustainable landscapes: A case study of the 'Mayan Zone' in Quintana Roo, México. Land Use Policy 21(4):333-346.

Busch, C. \& J. Geoghegan. 2010. Labor scarcity as an underlying cause of the increasing prevalence of deforestation due to cattle pasture development in the southern Yucatán region. Regional Environmental Change 10(3):191203.

Carte, L., M. McWatters, E. Daley \& R. Torres. 2010. Experiencing agricultural failure: Internal migration, tourism and local perceptions of regional change in the Yucatán. Geoforum 41:700-710.

Chowdhury, R.R. 2010. Differentiation and concordance in smallholder land use strategies in southern Méxi- co's conservation frontier. Proceedings of the National Academy of Sciences of the United States of America 107(13):5780-5785.

CONANP. 2011. Mapa de las Áreas Naturales Protegidas Federales de México. Comisión Nacional de Áreas Naturales Protegidas, Morelia, Michoacán. http://sig.conanp. gob.mx/website/anpsig/viewer.htm (October 4, 2011).

Daily, G.C., T. Söderqvist, S. Aniyar, K. Arrow, P. Dasgupta, P.R. Ehrlich, C. Folke, A. Hansson, B.-O. Jansson, N. Kautsky, S. Levin, J. Lubchenco, K.-G. Mäler, D. Simpson, D. Starrett, D. Tilman \& B. Walker. 2000. The value of nature and the nature of value. Science 289:395-396.

Dalle, S.P., M.T. Pulido \& S. de Blois. 2011. Balancing shifting cultivation and forest conservation: Lessons from a "sustainable landscape" in southeastern México. Ecological Applications 21(5):1557-1572.

de Haas, H. 2010. Migration and development: A theoretical perspective. International Migration Review 44:227264.

de Sherbinin, A., D. Balk, K. Yager, M. Jaiteh, F. Pozzi, C. Giri \& A. Wannebo. 2002 A CIESEN Thematic Guide to Social Science Applications of Remote Sensing. Columbia University, Center for International Earth Science Information Network (CIESIN), Palisades, NY.

Defries, R., G. Asner, F. Achard, C. Justice, N. Laporte, K. Price, C. Small \& J. Townshend. 2005. Monitoring tropical deforestation for emerging carbon markets. Pp. 3544 in Tropical Deforestation and Climate Change. Edited by M.A. Schwartzman. IPAM and Environmental Defense, Belem, Brazil and Washington, DC.

Garcia-Frapolli, E., B. Ayala-Orozco, M. Bonilla-Moheno, C. Espadas-Manrique \& G. Ramos-Fernandez. 2007. Biodiversity conservation, traditional agriculture and ecotourism: Land cover/land use change projections for a natural protected area in the northeastern Yucatán Peninsula, México. Landscape and Urban Planning 83(2-3):137-153.

Geist, H.J. \& E.F. Lambin. 2002. Proximate causes and underlying driving forces of tropical deforestation. BioScience 52:143-150.

Geoghegan, J., S. Villar, P. Klepeis, P. Mendoza, Y. Ogneva-Himmelberger, R. Chowdhury, B.L. Turner \& C. Vance. 2001. Modeling tropical deforestation in the southern Yucatán peninsular region: Comparing survey and satellite data. Agriculture, Ecosystems, and Environment 84:2546.

Green, G.M., C.M. Schweik \& J.C. Randolf. 2005. Retrieving land-cover change information from Landsat satellite images by minimizing other sources of reflectance vari- 
ability. Pp. 131-160 in Seeing the Forest and the Trees: Human-environment interactions in forest ecosystems. Edited by E.F. Moran \& E. Ostrom. MIT Press, Cambridge, MA.

Gurri, F.D. 2010. Smallholder land use in the southern Yucatán: How culture and history matter. Regional Environmental Change 10:219-231.

Hartter, J., C. Lucas, A.E. Gaughan \& L. Lizama Aranda. 2008. Detecting tropical dry forest succession in a shifting cultivation mosaic of the Yucatán Peninsula, México. Applied Geography 28(2):134-149.

Hecht, S. 2010. The new rurality: Globalization, peasants and the paradoxes of landscapes. Land Use Policy 27(2):161.

Hoekstra, J.H., J.M. Boucher, T.H. Ricketts \& C. Roberts. 2005. Confronting a biome crisis: Global disparities of habitat loss and protection. Ecology Letters 8:23-29.

Houghton, R.A., D.L. Skole, C.A. Nobre, J.L. Hackler, K.T. Lawrence \& W.H. Chomentowski. 2000. Annual fluxes of carbon from deforestation and regrowth in the Brazilian Amazon. Nature 403:301-304.

IGBP. 1999. International Geosphere-Biosphere Programme. The role of biospheric feedbacks in the hydrological cycle. Global Change Newletter (The IGBP-BAHC Special Issue) No. 39. International Geosphere-Biosphere Programme, Stockholm.

INEGI. 2011. Censo de población y vivienda 2010. Instituto Nacional de Estadística y Geografía, Aguascalientes, Ags. www.censo2010.org.mx/ (October 1, 2011).

Keys, E. 2004. Jalepeno pepper cultivation: Emergent commercial land use. Pp. 207-220 in Integrated LandChange Science and Tropical Deforestation in the Southern Yucatán. Edited by B.L. Turner II, J. Geoghegan \& D. Foster. Oxford University Press, Oxford.

Kinnaird, M.F., E.W. Sanderson, T.G. O'Brien, H.T. Wibisono \& G. Woolmer. 2003. Deforestation trends in a tropical landscape and implications for endangered large mammals. Conservation Biology 17:245-257.

Klepeis, P. \& C. Vance. 2003. Neoliberal policy and deforestation in southeastern Mexico: An assessment of the PROCAMPO program. Economic Geography 79(3):221240.

Kremen, C., J.O. Niles, M.G. Dalton, G.C. Daily, P.R. Ehrlich, J.P. Fay, D. Grewel \& R.P. Guillery. 2000. Economic incentives for rainforest conservation across scales. Science 288:1828-1832.
McKillop, H. 2004. The Ancient Maya: New perspectives. W. W. Norton \& Company, Inc. , New York.

Mertens, B., W.D. Sunderlin, O. Ndoye \& E.F. Lambin. 2000. Impact of macroeconomic change on deforestation in South Cameroon: Integration of household survey and remotely-sensed data. World Development 28(6):983999.

Nagendra, H., J. Southworth \& C. Tucker. 2003. Accessibility as a determinant of landscape transformation in western Honduras: Linking pattern and process. Landscape Ecology 18(2):141-158.

Naidoo, R., A. Balmford, R. Costanza, B. Fisher, R.E. Green, B. Lehner, T.R. Malcolm \& T.H. Ricketts. 2008. Global mapping of ecosystem services and conservation priorities. Proceedings of the National Academy of Sciences, U.S. 105:9495-9500.

Porter-Bolland, L., E.A. Ellis \& H.L. Gholz. 2007. Land use dynamics and landscape history in La Montana, Campeche, México. Landscape and Urban Planning 82(4):198-207.

Poyatos, R., J. Latron \& P. Llorens. 2004. Land use and land cover change after agricultural abandonment. Mountain Research and Development (4):362-368.

Radel, C., B. Schmook \& S. McCandless. 2010. Environment, transnational labor migration, and gender: case studies from southern Yucatán, México and Vermont, USA. Population and Environment 32(2-3):177-197.

Robson, J.P. 2010. The Impact of Rural to Urban Migration on Forest Commons in Oaxaca, México. Ph.D. Thesis. Unversity of Manitoba, Winnipeg, Canada.

Robson, J.P. \& F. Berkes. 2011a. How does out-migration affect community institutions? A study of two indigenous municipalities in Oaxaca, México. Human Ecology 39(2):179-190.

Robson, J.P. \& F. Berkes. 2011b. Exploring some of the myths of land use change: Can rural to urban migration drive declines in biodiversity? Global Environmental Change 21(3):844-854.

Rudel T.K., D. Bates \& R. Machinguiashi. 2002. A tropical forest transition? Agricultural change, out-migration, and secondary forests in the Ecuadorian Amazon. Annals Of The Association Of American Geographers 92(1):87-102.

Rudel, T.K., O.T. Coomes, E. Moran, F. Achard, A. Angelsen, J. Xu \& E. Lambin. 2005. Forest transitions: towards a global understanding of land use change. Global Environmental Change Part A 15(1):23-31. 


\section{Hopkins et al. - Linking remote sensing, census and interview data to understand forest transitions in the state of Yucatan, Mexico}

Rueda, X. 2010. Understanding deforestation in the southern Yucatán: Insights from a sub-regional, multi-temporal analysis. Regional Environmental Change 10(3):175-189.

Salvador Flores, J. \& I. Espejel Carvajal. 1994. Tipos de Vegetación de la Peninsula de Yucatán. Universidad Autónoma de Yucatán, Dirección General de Extension, Mérida, Yucatán, México.

Schmook, B. \& C. Radel. 2008. International labor migration from a tropical development frontier: Globalizing households and an incipient forest transition: the southern Yucatán case. Human Ecology 36:891-908.

Schroth, G. \& J.A. McNeely. 2011. Biodiversity conservation, ecosystem services and livelihoods in tropical landscapes: towards a common agenda. Environmental Management 48:229-236.

SEDUMA. 2011. Áreas Naturales Protegidas. Gobierno del Estado de Yucatán, Merida, Yucatán. www.seduma. Yucatán.gob.mx/areas-naturales/index.php (October 4, 2011).

SEGOB. 1988. Los municipios de Yucatán. Secretaria de Gobernación, México. Colección Enciclopedia de los municipios de México, Volume 30. Centro Nacional de Desarrollo Municipal [CEDEMUN], Secretaría de Gobernación [SEGOB], and Gobierno del Estado de Yucatán, México, D.F.

Siegel, J.S. \& D.A. Swanson. 2004. Editors of Methods and Materials of Demography. Academic Press, Boston.

Sohn, Y., E. Motan \& F. Gurri. 1999. Deforestation in north-central Yucatán (1985-1995): Mapping secondary succession of forest and agricultural land use in Sotuta using the cosine of the angle concept. Photogrammetric Engineering \& Remote Sensing 65(8):947-958.

Southworth, J. \& H. Nagendra. 2010. Reforestation: challenges and themes in reforestation research. Pp. 1-14 in Reforesting Landscapes: Linking pattern and process. Edited by J. Southworth \& H. Nagendra. Springer, New York.
Southworth, J. \& C. Tucker. 2001. The influence of accessibility, local institutions, and socioeconomic factors on forest cover change in the mountains of Western Honduras. Mountain Research and Development 21(3):276-283.

Trivedi, M.R., A.W. Mitchell, N. Mardas, C. Parker, J.E. Watson \& A.D. Nobre. 2009. REDD and PINC: A new policy framework to fund tropical forests as global 'eco-utilities'. Institute of Physics Conference Series: Earth and Environmental Science 8:1-11.

Turner II, B., S. Villar, D. Foster, J. Geoghegan, J. Keys, P. Klepeis, D. Lawrence, P. Mendoza, S. Manson, Y. Himmelberger, et al. 2001. Deforestation in the southern Yucatán peninsular region: An integrative approach. Forest Ecology and Management 154:353-270.

Unruh, J., H. Nagendra, G. Green, W. McConnell \& N. Vogt. 2005. Cross-continental comparisons: Africa and Asia. Pp. 303-324 in Seeing the Forest and the Trees: Human-environment interactions in forest ecosystems. Edited by E. Moran \& E. Ostrom. MIT, Cambridge, MA.

Walsh, S.J., Y. Shao, C.F. Mena \& A.L. McCleary. 2008. Integration of hyperion satellite data and a household social survey to characterize the causes and consequences of reforestation patterns in the northern Ecuadorian Amazon. Photogrammetric Engineering and Remote Sensing 74(6):725-735.

Wood, C. \& D. Skole. 1998. Linking satellite, census, and survey data to study deforestation in the Brazilian Amazon. Pp. 70-93 in People and Pixels: Linking Remote Sensing and Social Science. Edited by D. Liverman, E. Moran, R. Rindfuss \& P. Stern. National Academy Press, Washington D.C.

Wyman, M., Z. Gomez Villegas \& I. Miranda Ojeda. 2007. Land-use/land-cover change in Yucatán State, México: An examination of political, socioeconomic, and biophysical drivers in Peto and Tzucacab. Ethnobotany Research \& Applications 59-66. 
